\title{
4
}

\section{Signals for Emerging Technologies in Paper and Packaging Industry}

\author{
Karvonen Matti and Kässi Tuomo \\ Lappeenranta University of Technology \\ Finland
}

\section{Introduction}

The paper industry is undergoing significant changes in its business environment as both media and the packaging industries are constantly striving for inexpensive methods to add new functionalities in their products and to develop their processes. Other industries, such as the ICT, electronics and food industry look at printing as an economical method for mass production which also creates new applications and opportunities. The development has lead to the convergence or fusion of technologies. In previous research the phenomenon of convergence has received particular attention within the information and communication technologies (ICT) (e.g. Duysteers \& Hagedoorn, 1998; Lei, 2000; Stieglitz, 2003; Wirtz, 2001). Despite the fact many industries are facing trends of convergence, the phenomenon has remained largely unexplored in the academic management field. Blurring, or even disappearance, of industry boundaries, overlapping technologies and markets are used to describe this phenomenon.

Patents have been recognised as a very rich data source for the study of innovation and technical change and there are many applications of patent analysis (see Lai et al., 2006). The innovative performance of organisations have been analysed with indicators such as research and development expenditures (R\&D inputs), patents, patent citations and new product announcements. Increasingly researchers in technology management are using patent citations as an indicator of companies' innovation performance. One line of research counts the number of times a patent is cited in subsequent citations (forward citation) to measure its value or importance (Trajtenberg, 1990; Hall et al., 2005). A second line of research is interested in spillovers and knowledge flows and uses citations as indicators of knowledge transmission between inventors, firms and industrial sectors (Hall et al., 2001; Jaffe et al., 2000) The advantages and limitations (Table 1) of using patent data in economic research are widely discussed in the literature.

Patents are generally regarded as the precursors of technological development. Patent information is mainly intended for specialists, but especially their relations to other patents can make patents a valuable source of knowledge also for non-specialists trying to identify general trends. In this paper we first briefly define one special case of technological change, namely, the phenomenon of convergence. After introducing convergence, we provide evidence of the technological development in the printing and electronics industries. International patent classification (IPC) data is used to study whether there has been a growing overlap of the technological areas in which different industrial sectors are 


\begin{tabular}{|c|c|}
\hline $\begin{array}{l}\text { Advantages and } \\
\text { Opportunities }\end{array}$ & Limitations and Challenges \\
\hline $\begin{array}{l}\text { - Highly detailed information on the invention } \\
\text { - A homogenous measure of technological } \\
\text { novelty and available for a long time series } \\
\text { - Includes citations of previous patents and the } \\
\text { scientific literature } \\
\text { - possibility to study spillovers } \\
\text { - } \quad \text { evaluates the value of innovations } \\
\text { - evaluates the "originality" and "generality" } \\
\text { of innovations } \\
\text { - A largely available stock of patents } \\
\text { - Data contained in patents are supplied in } \\
\text { voluntary basis } \\
\text { - Possibility (regardless of the challenges) } \\
\text { to integrate data into other complementary } \\
\text { information (financial data, alliance data etc.) }\end{array}$ & $\begin{array}{l}\text { - Not all innovations are patented } \\
\text { - } \text { does not meet patentability criteria } \\
\text { of appropriability } \\
\text { - Inter-industry and inter-firm differences in } \\
\text { the propensity to patent } \\
\text { - } \quad \text { Filing patents under different names (e.g. } \\
\text { subsidiaries) } \\
\text { - Differences across countries in economic costs } \\
\text { and benefits of patents } \\
\text { - Interpreting findings of the citation analysis } \\
\text { requires at least minimum knowledge of } \\
\text { patenting search procedures and reports in } \\
\text { different countries } \\
\text { - “Truncation“ problem in evaluating the } \\
\text { importance of very recent inventions }\end{array}$ \\
\hline
\end{tabular}

Table 1. Advantages and limitations of patent analysis (Griliches, 1990; Hall et al., 2001; Michel \& Bettels, 2001; Thoma \& Torrisi, 2007)

operating, or whether technological profiles at the industry level remain distinct. Patent citation data is used to provide insights into the importance of technological transition of the paper and printing firms. Patent citations are used, because the value of patent counts as a proxy for R\&D success is severely limited by the large variance in the significance of individual patents (e.g. Hall et al., 2005). All in all, the study has three main objectives. First, patents are used to find out converging technology areas between paper and electronics. Secondly, citations received are used to provide insights into future competition between the players. Thirdly, we analyse the pioneering innovations of the players in order to evaluate the breakthrough innovations of the players and discuss the opportunities and challenges of using patent data in the industry analysis.

The paper is structured as follows: Section 2 outlines the convergence phenomenon and characterises the emerging printed intelligence industry. Section 3 describes the data and methods used. Section 4 presents the empirical results and finally the study is concluded and discussed in Section 5.

\section{Convergence evolution and the printed intelligence industry}

\subsection{Convergence}

Convergent developments (Figure 1) and the emerging new industry segment between industries will potentially mean to fundamental changes leading to opportunities and challenges alike.

In the process of convergence, the technology bases of companies are becoming increasingly similar, which eventually means that companies compete with the same technological competencies. A new industry segment will either replace former segments or complement them at their intersection (Dowling et al., 1998; Bröring et al., 2006). In the "substitutive 


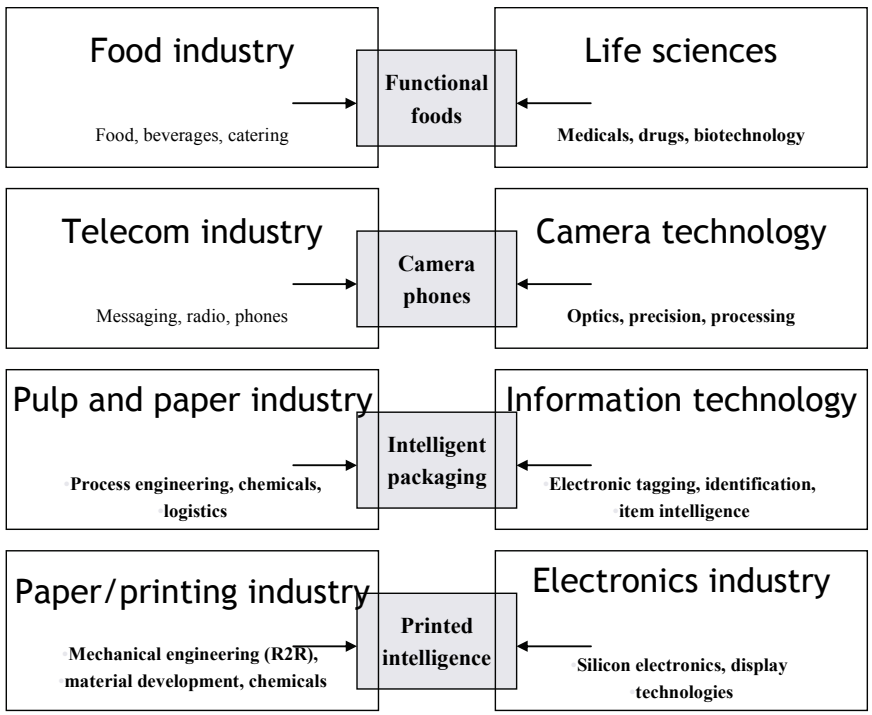

Fig. 1. Examples of convergent developments

paradigm" the new industry segment will replace the former segments $(1+1=1)$ leading to competitive convergence. In the "cooperative paradigm" a new market emerges $(1+1=3)$ that requires the combination of resources and competencies from previously separate industries (e.g. through strategic alliances or other forms of collaboration) leading to complementary convergence. (Dowling et al., 1998) In the "coopetitive paradigm" convergence may imply a need to collaborate and compete at the same time. All in all, convergence typically changes the basis for competitive advantage and firms must adapt their strategies depending on the nature and degree of convergence.

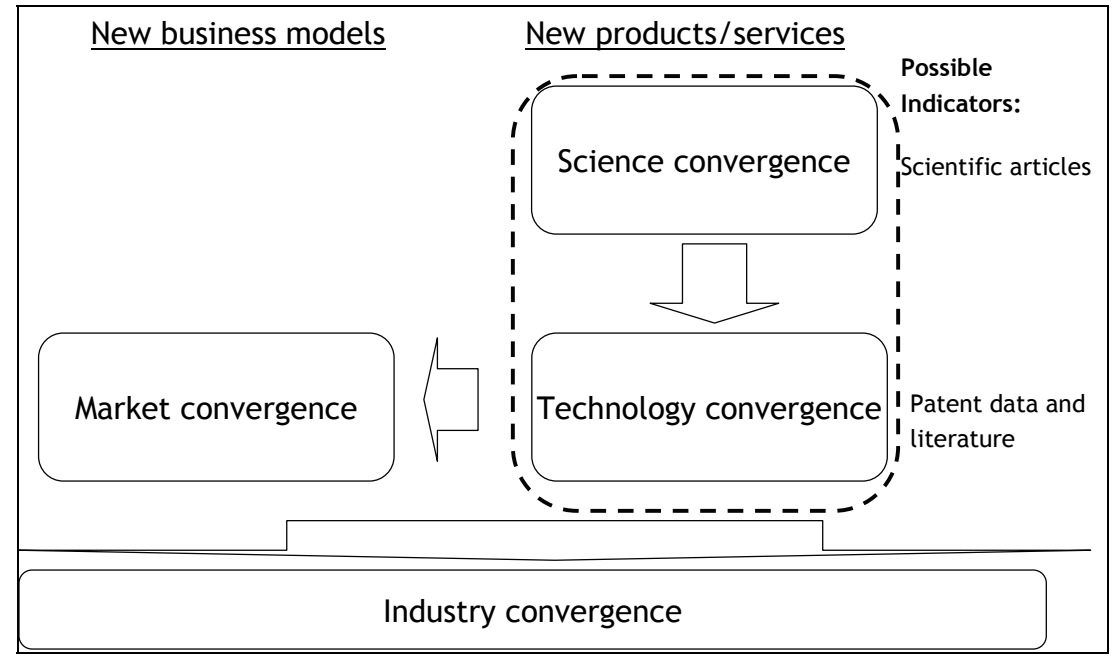

Fig. 2. Phases of convergence (Curran \& Leker, 2010) 
Curran \& Leker (2009) base their concept of anticipating convergence upon the assumption of an idealised time series of events (Figure 2) starting with scientific disciplines, where distinct disciplines begin to cite each other and eventually develop further into closer research collaboration. After the distance between basic sciences has been decreasing, applied science and technology development should follow, leading to technology convergence. Then in market convergence, new product market combinations will emerge, and finally the fusion of firms and industry segments will lead to industry convergence.

Due to its high strategic importance, an early identification of trends of convergence and anticipation of changing industry structures matters to all stakeholders, including managers, academics and regulators. Anticipating and monitoring the stages of convergence process would enable firms to develop new competences, and form strategic alliances or acquire new technologies at the early stages. (Duysteers \& Hagedoorn, 1998; Curran et al., 2010)

\subsection{The RFID and printed intelligence industry}

Printed functionality (or intelligence) means adding new functionalities into a flexible substrate, typically paper and plastics, in addition to regular graphical properties by using printing methods. Printed intelligence can be codes containing links to additional information. Such codes include one- and two-dimensional bar codes as well as invisible, reactive and electronic codes. Furthermore, printed functionality can be visual effects and images, electronics, optics and displays as well as sensors and indicators. The term hybrid media is related to printed functionality and is defined as the integration of different media, contents and functionalities, especially the convergence between fibre-based products and electronic media. Electronic paper belongs to the same context, even if the substrate here is plastics rather than fibre-based materials. Figure 3 shows how print media, electronic media, printed functionality and hybrid media interconnect. In the figure printed means that every part of a certain component is made by using printing methods, and printed/attached means that some parts of the component can be done by other means besides printing. One example is the radio frequency identification (RFID) tag where the antenna is printed and the chip attached to the printed antenna by other means. (Hakola et al., 2006)

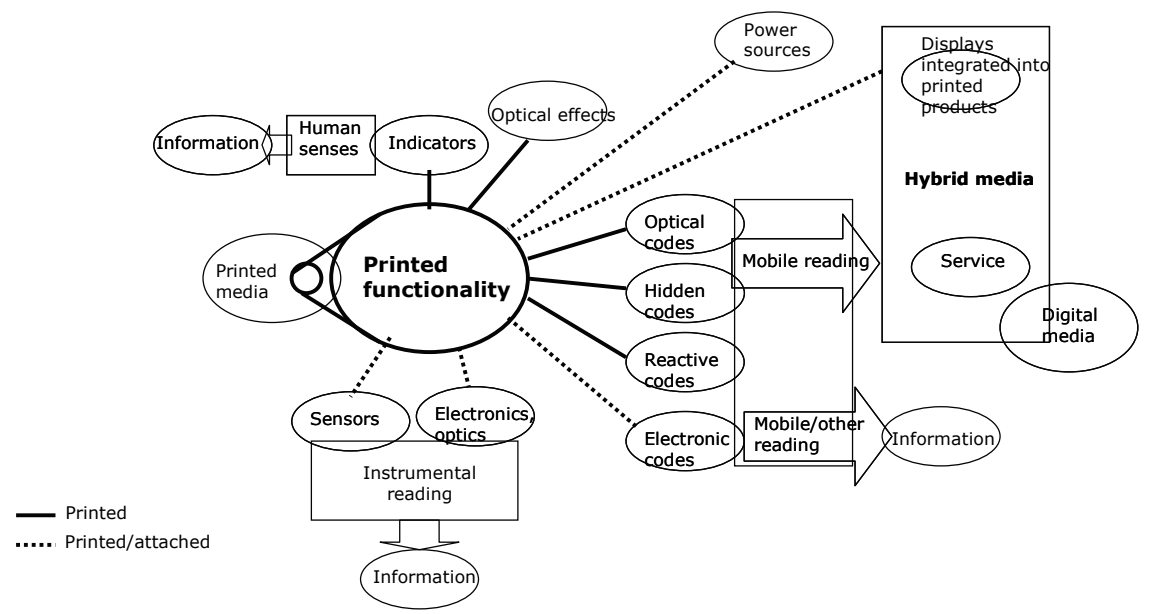

Fig. 3. The definition of printed intelligence and hybrid media (Hakola et al., 2006) 
A smart or intelligent system can be defined to be one that has an inherent ability to gather information on its operating environment or history, to process information, to draw intelligent conclusions from it, and finally to act on those inferences by changing its characteristics in an advantageous manner. The most important development areas of intelligent packages can be defined to be concerned with product authenticity, anti theft or tamper evidence, track and trace, and brand enhancement. Possible technologies include electronic article surveillance (EAS), radio frequency identification (RFID), and other electronics or magic inks (IDTechEx, 2006). RFID technology can be regarded as the most mature smart development area (Aho, 2003).

RFID technology is a data collection and transfer technology that uses radio frequency waves to transfer data between a reader and an item. The RFID system consists of three basic components: a tag, a reader, and back office data-processing equipment. The tag contains unique identification information about the item to which it is attached; the reader emits and receives radio waves to read the information stored in the tag, and the dataprocessing equipment processes all the collected data (Wu et al., 2006). Tags can be active or passive: Active tags have a battery, whereas the passive tags use energy from the reader's signal to power-up the integrated circuit and transmit stored data back.

Today, most RFID tags contain a silicon chip and copper-etched circuit boards. This traditional technology sets limitations to production speed and capacity, and furthermore, the method is environmentally unfriendly. New roll-to-roll (R2R)-printing technology allows the use of a rotary-screen, lithographic, gravure or flexography press at a much higher production speed. Digital inkjet technology could also be used as an alternative method. At first, the antenna is printed and then the integrated circuit is attached or alternatively both are printed. The inlay is typically then placed on a label substrate. (Lynn 2005) Eventually, printed RFID (Lynn 2005; Harrop \& Das 2008; Fortunato et al. 2008; Österbacka 2008) manufactured by efficient (R2R)- manufacturing method (Kesola 2007) is probably going to gain market share, and low-cost item-level RFID tagging could lead to peak in the industry sales.

According to Harrop \& Das (2008), low cost flexible substrates are needed in order to open up new potential markets, since the applications of printed electronics are very price sensitive. The most popular substrates today are polyethylene thin films, but paper substrates offer low costs for processes, which can tolerate the rough surface of paper.

According to (Ngai et al. 2008), RFID systems have been applied, in particular, in supply chain management and manufacturing, but the potential application areas are much broader. Enterprises and entities today utilize RFID successfully in their every day operations for a wide variety of application areas. Most cases in the beginning of 2008 occurred in retail and consumer goods category, mainly because of mandates by major retailers and military organizations.

Passenger transport represented the second biggest application area. Many executed projects in the leisure application area came from one time events. Finance, security and safety sectors were also steadily growing and driven for example by counterfeiting and terrorism. Land and sea logistics is another steadily growing area. The total RFID market was worth about five billion US dollars in 2007, and it is forecasted to reach 27 billion US dollars in 2018, biggest potential being in East Asia, followed by North America and Europe. (Das \& Harrop 2008) According to (Seppä \& Uusikylä 2009) RFID could create a revolutionary innovation during 2010s in case Internet and mobile phones, capable to 
communicate with RFID identifiers can be successfully interlinked. This could provide a possibility for myriad services literally to all products.

Electronic paper is a thin display technology designated to mimic the appearance of regular ink on paper. First commercial applications are used in electronic books as memory displays and advertisement signs in firms. Electronic ink refers to the field of technologies that can display persistent text and graphics and where the text and graphics are imprinted via use of electronic means. According to Aho (2003), conducting polymers have responses in their physical properties to various external stimuli, and another point of view in the combining conducting polymers and paper is printed electronics. Applications of conducting polymers include e.g. electronic components, optoelectronic devices and sensors. The aim of several research groups is to produce disposable, low-cost, and flexible laminar electronics produced using additive reel-to-reel techniques. With the help of printed electronics on paper the electronics industry could respond to the legislation demands of the future, and some laminar electronics have already been realised, such as the silicon transistor using reelto-reel manufacturing, all-polymer transistor by screen printing, printed all-polymer fieldeffect transistor, all-organic printed rectifier, all-polymer RC filter circuit by ink-jet printing, and printed battery (Aho, 2003). Ink-jet printing seems to get more and more attention. Paper as a flexible substrate has been used in transistors, circuit boards and batteries with other chemicals than conducting polymers.

\section{Methods and data}

In order to identify a firm's technological domains, the observed IPC codes in the firm's patent records were identified and classified into technology fields representing the firm's major business domains. Patent application in each field indicates an accumulation of knowledge and advancement in the technological trajectory (Fai \& Tunzelmann, 2001). IPC codes are a hierarchical way of assigning the category to which every patent belongs. There are 8 sections, 120 classes, 628 sub-classes and about 70,000 groups. In our analysis we have utilised a higher level classification, by which the 628 sub-classes are aggregated into 35 technological fields, and these are further aggregated into five main categories: Electrical engineering, Instruments, Chemistry, Mechanical engineering and Others. (Appendix 1, WIPO, 2008) From the paper \& printing industry point of view we will call categories Chemistry and Mechanical engineering as "traditional fields" and Electrical engineering and Instruments as "emerging fields".

\subsection{Citation analysis in convergent industry environments}

The "backward citations" (i.e. citations made) in the patent document position the new invention technologically with respect to previous patents and "forward citations" represent citations received by the patent. Forward citations (citations made by other patents) are considered to reflect the patent's technological significance, the applicability and the ability of the inventors to benefit from their inventions, namely, their appropriability.

One aspect is to what extent patents are cited by the same assignee (we refer to these as selfcitations) as presumably citations that belong to the same assignee represent transfers of knowledge that are mostly internalised. Self-citations would suggest that the firm has a strong competitive position in the particular technology and is in a position to internalise the knowledge created by its own developments. Hall et al. (2005) found that patent citations could provide a more accurate picture of the company's intangible assets and in 
particular, the value potential captured seemed to be enhanced in settings where forward citations are made by the inventor.

We distinguish self citations from external citations, and further divide external citations into two groups: within the industry and beyond the industry citations (Figure 4).

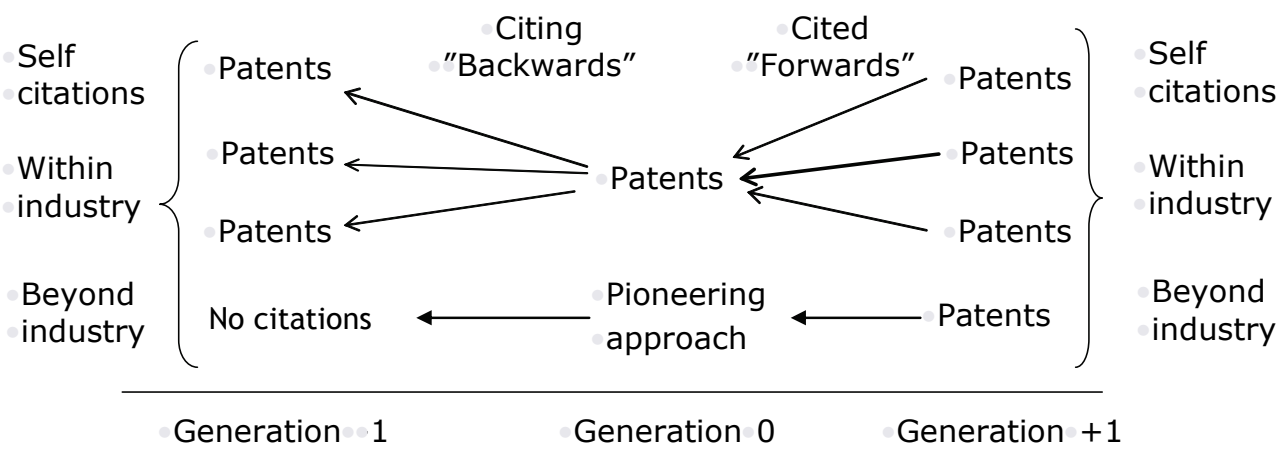

Fig. 4. Different types of citations

Self citations typically imply a more competitive position in that field (capability), external citations may suggests that the citing firm is entering a technological competition within (competition) or beyond (diversification) industry. Generally we expect that in convergent environments spill-over effects from extra industry increases and the gradual diversification to the new fields is evolving. Forward citations provide indications about the future success of these new inventions and the future competition between the players. In addition we can distinguish the inventions which have not made any backward citations, but have received many citations, which we call "pioneering innovations".

\subsection{Sample and databases}

Our analysis is based on the links between two datasets. The primary source for acquiring the list of companies and their activities in the RFID field was an independent consultancy company (Das \& Harrop, 2008), and the companies were in further analyses categorised into four groups: value chain's upstream focused players, downstream focused players, vertically integrated firms, and paper and printing companies. Upstream players are involved in developing, manufacturing and selling identifiers such as chips, antennas, tags and labels, or devices such as readers and printers. Downstream focused firms are involved in software and integration, and they operate closely in the end customer interface. Vertically integrated firms operate broadly in the whole value chain with activities both upstream and downstream of the value chain. In addition we separately analysed printing and paper companies operating in the field. The concordance, based on Smoch et al. (2003), between paper and publishing and electronics industry classification and the companies evaluated are presented in Appendix 2.

Information on patenting was drawn from the EPO Worldwide Patent Statistical Database. The coverage of the database regards documents from more than 80 patent offices worldwide since the 1970s. This worldwide statistical patent database, also known as PATSTAT, was developed by the EPO in 2005 and first published in April 2006. The elements of PATSTAT are the title and abstract of application, filing, priority and 
publications dates of the application, applicants and inventors and detailed addresses, the IPC classification symbol and priority applications. Moreover, PATSTAT provides complementary information, for example, on the citation links such as the category of the citation, citation identification, origin of the citation and non-patent literature bibliography. (EPO, 2008) In this study we used these data mainly to identify (1) in which IPC classes the players have patented and to find converging technology areas, (2) forward citations of patents in order to evaluate the impact and value of innovations in the converging industry sectors and (4) the pioneering innovations of the players.

\section{Empirical results}

\subsection{Patenting in traditional and emerging fields}

In the analysis there were altogether 87 firms which were categorised into four different clusters under the following headings: upstream focused players $(\mathrm{N}=26)$, vertically integrated players $(\mathrm{N}=23)$, downstream players $(\mathrm{N}=17)$ and paper \& printing companies. In the empirical part we analysed each cluster patents and their forward citations in the years 1960-2006. The analysed firms had altogether 464,225 patent applications and the top 50 IPC classes in each cluster. The players' (Table 2) patent distribution clearly shows that downstream players have the most focused technological competencies as $95.8 \%$ patents are related to electrical engineering patents and the paper and printing firms have the most diversified patent portfolio.

\begin{tabular}{|c|c|c|c|c|}
\hline $\begin{array}{c}\text { Industry / } \\
\text { IPC group }\end{array}$ & $\begin{array}{c}\text { Paper \& } \\
\text { Printing } \\
\mathbf{( N = 1 8 )}\end{array}$ & $\begin{array}{c}\text { Upstream } \\
\text { electronics } \\
\mathbf{( N = 2 6 )}\end{array}$ & $\begin{array}{c}\text { Vertically } \\
\text { integrated } \\
\text { electronics } \\
\mathbf{( N = 2 3 )}\end{array}$ & $\begin{array}{c}\text { Downstream } \\
\text { electronics } \\
\mathbf{( N = 1 7 )}\end{array}$ \\
\hline Patent count & 77,963 & 124,184 & 218,560 & 43,518 \\
\hline $\begin{array}{c}\text { TOP50 IPC } \\
\text { (\%/all) }\end{array}$ & $84.7 \%$ & $87.6 \%$ & $91.7 \%$ & $98.0 \%$ \\
\hline $\begin{array}{l}\text { I Electrical } \\
\text { engineering }\end{array}$ & $22.3 \%$ & $80.8 \%$ & $88.7 \%$ & $95.8 \%$ \\
\hline $\begin{array}{l}\text { II Instruments } \\
\text { III Chemistry }\end{array}$ & $16.5 \%$ & $16.2 \%$ & $6.9 \%$ & $3.3 \%$ \\
\hline $\begin{array}{l}\text { IV Mechanical } \\
\text { engineering }\end{array}$ & $41.4 \%$ & $0.5 \%$ & $1.6 \%$ & $0.0 \%$ \\
\hline
\end{tabular}

Table 2. The players' patents distribution to the technological fields 1978-2006

Paper and printing firms have traditionally been strong in mechanical engineering and chemistry patents. In the sample, $41.4 \%$ of the paper and printing firms' patents were related to mechanical engineering. Figure 5 suggests that there has been a change in the focus for the paper and printing industry in the recent years. With the emergence of printed intelligence and RFID there has been a significant increase in patenting in the new fields. 


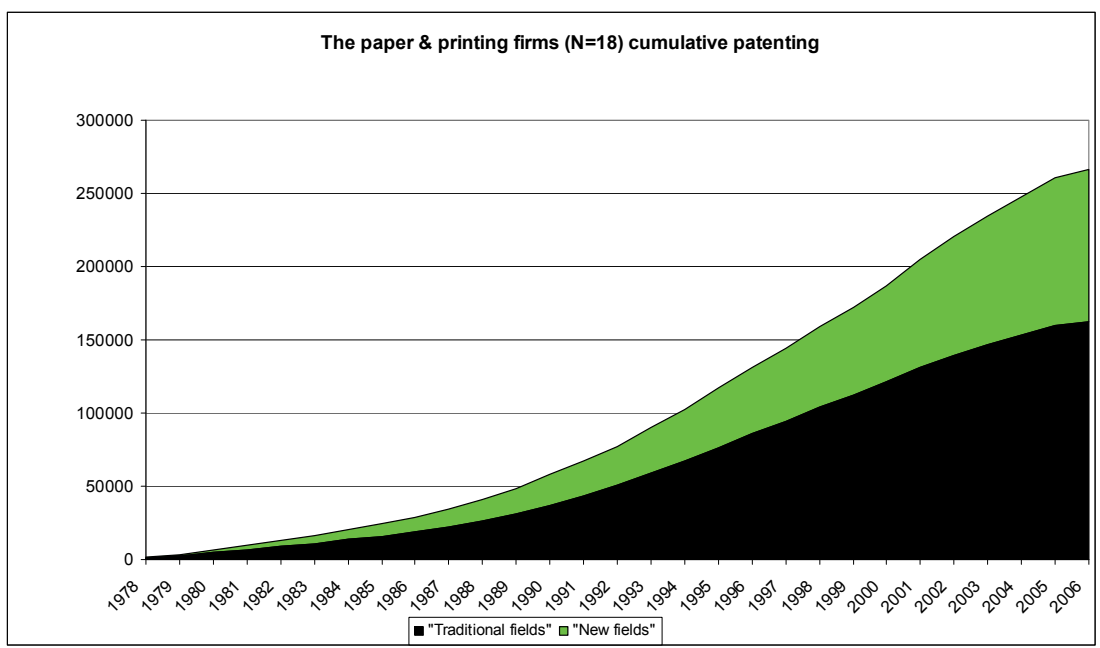

Fig. 5. The paper \& printing firms cumulative patenting in traditional and emerging fields

\subsection{Citations received and dominance of emerging technologies}

The analysed firms had received altogether 1,389,224 citations to the patents, of which $144,479(10.4 \%)$ were self-citations. Table 3 shows that vertically integrated firms have received overwhelmingly most of the citations with an average of over four citations per patent. The paper and printing firms have received only 0.91 citations per patent. We analysed TOP50 IPC classes citations received for each cluster and their distribution to the technological fields.

\begin{tabular}{|c|c|c|c|c|}
\hline $\begin{array}{l}\text { Industry / } \\
\text { IPC group }\end{array}$ & $\begin{array}{c}\text { Paper \& } \\
\text { Printing } \\
(\mathrm{N}=18)\end{array}$ & $\begin{array}{l}\text { Upstream } \\
\text { electronics } \\
(N=26)\end{array}$ & $\begin{array}{c}\text { Vertically } \\
\text { integrated } \\
\text { electronics } \\
(\mathrm{N}=23)\end{array}$ & $\begin{array}{l}\text { Downstream } \\
\text { electronics } \\
(\mathbf{N}=17)\end{array}$ \\
\hline $\begin{array}{l}\text { Patent count } \\
\text { (Citations received) }\end{array}$ & 70,847 & 292,595 & 904,335 & 121,447 \\
\hline $\begin{array}{l}\text { Citations received } \\
\text { (average) }\end{array}$ & 0.91 & 2.36 & 4.14 & 2.79 \\
\hline $\begin{array}{l}\text { TOP50 IPC } \\
(\% / \text { all })\end{array}$ & $76.4 \%$ & $86.0 \%$ & $89.7 \%$ & $96.3 \%$ \\
\hline $\begin{array}{l}\text { Self-citation count } \\
(\%) \\
\text { - Within industry } \\
\text { - Beyond industry }\end{array}$ & $\begin{array}{l}5,951 \\
(8.4 \%) \\
71.4 \% \\
29.6 \% \\
\end{array}$ & $\begin{array}{c}29,260 \\
(10.0 \%) \\
86.0 \% \\
14.0 \% \\
\end{array}$ & $\begin{array}{c}96,764 \\
(10.7 \%) \\
89.3 \% \\
10.7 \% \\
\end{array}$ & $\begin{array}{c}13,237 \\
(10.9 \%) \\
95.8 \% \\
4.2 \% \\
\end{array}$ \\
\hline $\begin{array}{l}\text { External citations } \\
\text { - Within industry } \\
\text { - Beyond industry } \\
\end{array}$ & $\begin{array}{c}64,896 \\
(91.6 \%) \\
59.0 \% \\
41.0 \% \\
\end{array}$ & $\begin{array}{c}263,335 \\
(90.0 \%) \\
79.9 \% \\
20.1 \% \\
\end{array}$ & $\begin{array}{l}807,571 \\
(89.3 \%) \\
84.6 \% \\
15.4 \% \\
\end{array}$ & $\begin{array}{c}108,210 \\
(89.1 \%) \\
91.9 \% \\
8.1 \% \\
\end{array}$ \\
\hline
\end{tabular}

Table 3. The players' forward citations distribution to the technological fields 1978-2006 
The paper and printing firms' forward citations distribution between the technological fields shows a declining trend in the traditional fields, whereas the significance of electrical engineering patents has steadily increased. Many of the electrical engineering citations received is related to audio-visual technology, computer technology and semiconductors. The biggest growth in citations received has been in semiconductor device patents, indicating a growing competition especially with upstream electronics players. Regardless of the fact that as a whole vertically integrated players seem to be technology leaders, the paper and printing firms beyond industry self-citations indicate quite a strong capability development in new fields and received external citations indicate also market some market power in new fields.

\section{The dominance of emerging technologies}

The patent analysis reveals that from the paper and printing industry point of view the most important emerging technology fields are related to the computer technology (G06K; G06F), audio-visual technology (G09F; G11B; H04N; H05K); semiconductors (H01L), and optics (G02F; G02B; G03F, G03G1. Vertically integrated players have made most of the patents in computer technology, audio-visual technology and semiconductors, and the paper and printing firms have made most of patents related to optics. In the computer technology the downstream players have significantly increased their share (Figure 6) and recently even surpassed the integrated players. Integrated players have made very much self-citations in the computer technology indicating a very strong capability position in these technologies. The downstream players have also lately made a lot of self-citations in these technologies indicating an intensifying competition between the players. The paper and printing companies has quite a marginal share of computer technology patents.

Integrated players dominate also audio-visual technology patents, but the downstream have taken competitive position also in these technologies in the 2000's. Upstream players have taken stable $15 \%$ share of patents throughout the period, while in the paper and printing companies share have been moderately increasing. Interestingly, integrated players have made most of the self-citations and also upstream have made much self-citation, while there have been only marginal increase in the downstream players' self-citations.

In the semiconductor patents integrated players are strong, but upstream players are taking the dominance in the 2000's. In the optics patents (Figure 7) the paper and printing firms have made most of the patents and increased relative share throughout the period.

Table 4 shows a data of the patents and citations received to the emerging fields. The high figure of citations received of integrated players indicates that the patents have been technologically and economically significant. On the contrary the low figures of citations made and received by the paper and printing firms indicates that the spillover effect from emerging fields have not been so tremendous and the importance of new inventions have not been, at least so far, so extensive compared to other players. Of course, when

\footnotetext{
${ }^{1}$ G06K - Recognition of data; presentation of data; Record carriers; Handling; G06F Electric digital data processing; G11B - Information storage; H04N - Pictorial communication; H05K - Printed circuits; H01L - Semiconductor devices; G02F - Devices or arrangements; G02B - Optical elements, systems, or apparatus; G03F - Photomechanical production of textured or patterned surfaces; G03G Electrography; electrophotography; magnetography
} 
interpreting these results we have to remember the inter-industry differences in patenting practices. Downstream players have very focused technological competencies related to computer technology, and the citations indicate that the few patents in other fields seem to have been significant.

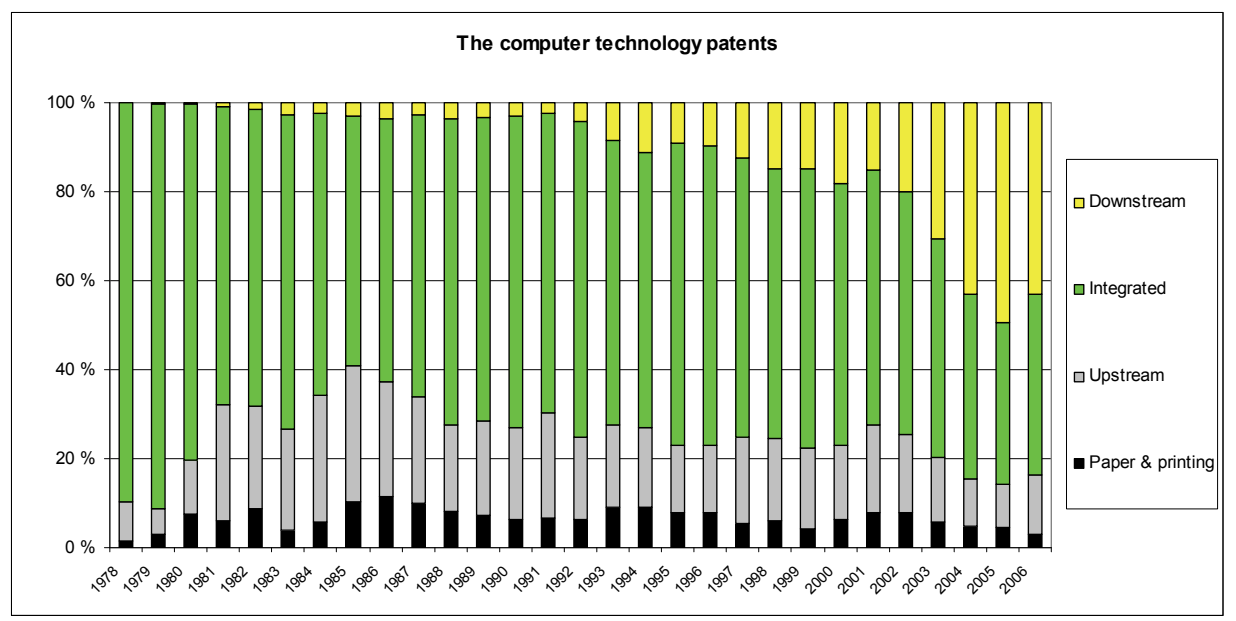

Fig. 6. The relative share of the computer technology patents 1978-2006

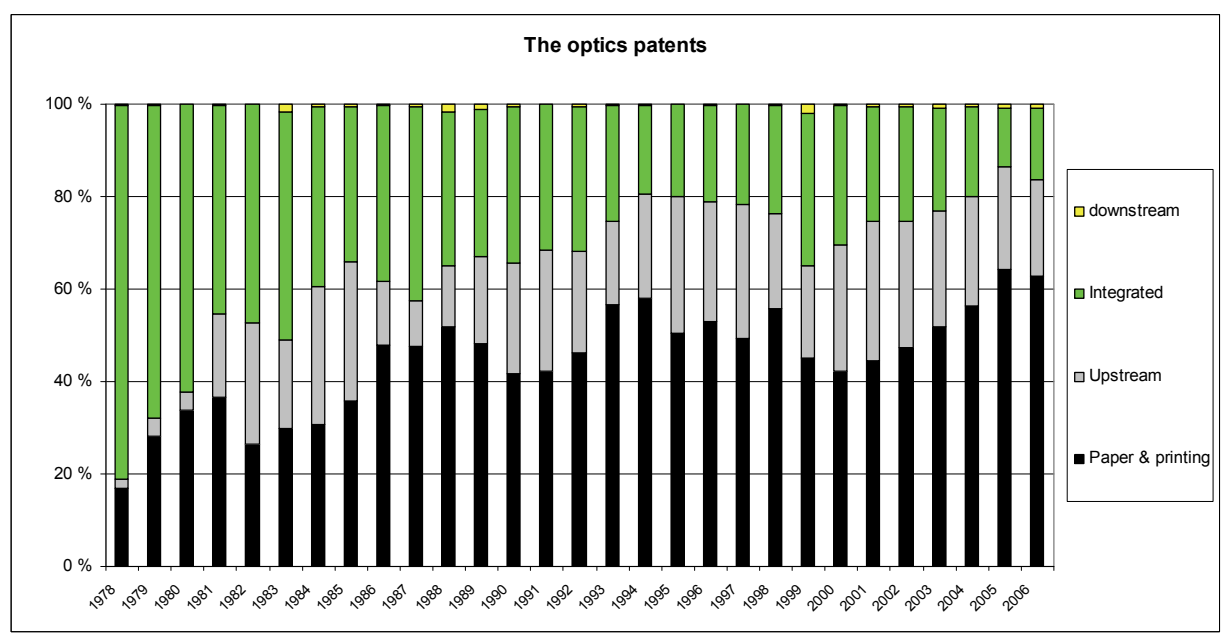

Fig. 7. The relative share of the optics patents 1978-2006 


\begin{tabular}{|c|c|c|c|c|c|}
\hline \multicolumn{2}{|l|}{$\begin{array}{l}\text { Industry/ } \\
\text { IPC group }\end{array}$} & \multirow{3}{*}{$\begin{array}{r}\begin{array}{l}\text { Paper \& } \\
\text { Printing } \\
(N=18)\end{array} \\
\\
\\
\\
\quad 8,970\end{array}$} & \multirow{3}{*}{$\begin{array}{l}\begin{array}{l}\text { Upstream } \\
\text { electronics } \\
(N=27)\end{array} \\
\\
23,701\end{array}$} & \multirow{3}{*}{$\begin{array}{l}\begin{array}{l}\text { Vertically } \\
\text { integrated } \\
\text { electronics }\end{array} \\
(\boldsymbol{N}=24) \\
\\
80,709\end{array}$} & \multirow{3}{*}{$\begin{array}{l}\begin{array}{l}\text { Downstream } \\
\text { electronics } \\
(\boldsymbol{N}=18)\end{array} \\
\\
29,516 \\
\end{array}$} \\
\hline Patents (IPC4) & & & & & \\
\hline $1978-2006$ & Computer technology & & & & \\
\hline & Audio-visual technology & 6,685 & 10,410 & 32,315 & 3,650 \\
\hline & Semiconductors & 5,224 & 29,519 & 29,761 & 241 \\
\hline & optics & 16,863 & 8,036 & 9,926 & 204 \\
\hline \multirow[t]{4}{*}{$\begin{array}{l}\text { Citations received/ } \\
\text { Patent } \\
\text { Self-citations (\%) }\end{array}$} & Computer technology & $\begin{array}{c}0.67 \\
6,007 \\
(5.2 \%)\end{array}$ & $\begin{array}{c}2.80 \\
66,343 \\
9.9 \%\end{array}$ & $\begin{array}{c}4.51 \\
364,230 \\
(14.8 \%)\end{array}$ & $\begin{array}{r}2.78 \\
82,245 \\
(12.8 \%)\end{array}$ \\
\hline & Audio-visual technology & $\begin{array}{c}0.95 \\
6,319 \\
(8.7 \%)\end{array}$ & $\begin{array}{c}2.47 \\
25,745 \\
(7.7 \%)\end{array}$ & $\begin{array}{c}4.47 \\
144,502 \\
(9.2 \%)\end{array}$ & $\begin{array}{c}3.25 \\
11,847 \\
(5.1 \%)\end{array}$ \\
\hline & Semiconductors & $\begin{array}{c}0.77 \\
4,000 \\
(4.0 \%)\end{array}$ & $\begin{array}{c}2.91 \\
86,032 \\
(13.3 \%)\end{array}$ & $\begin{array}{c}4.92 \\
146,562 \\
(11.9 \%) \\
\end{array}$ & $\begin{array}{c}6.50 \\
1,567 \\
(1.8 \%)\end{array}$ \\
\hline & optics & $\begin{array}{l}0.19 \\
13,384 \\
(10.3 \%)\end{array}$ & $\begin{array}{c}3.23 \\
25,919 \\
(7.2 \%)\end{array}$ & $\begin{array}{c}3.98 \\
39,456 \\
(5.9 \%)\end{array}$ & $\begin{array}{c}5.02 \\
1,024 \\
(6.8 \%)\end{array}$ \\
\hline
\end{tabular}

Table 4. The players' patents and forward citations in converging technology areas

In the semiconductor patents the integrated and upstream are the strongest players. Relatively the upstream players have increased their share mostly and have taken the dominant position and increased for example their self-citations significantly. However, in the citations received the integrated players have stayed as the dominant player. Paper and printing companies have taken the dominant position in patents related to optics. In the citations made, however, integrated and upstream players have made substantially more citation than the paper and printing companies. Integrated dominates also the citations received, whereas upstream and paper and printing companies have increased their share of forward citations. Paper and printing companies' self-citations to optics technologies, however, have increased throughout the period, indicating a strong competitive position in these fields.

\subsection{The pioneering innovations}

The distribution of pioneering innovations (Table 5) is quite similar compared to patent distribution, and so the players' have these more radical innovations mostly to their own strong technological fields.

Vertically integrated players have made most of the pioneering innovations, followed by upstream and paper and printing industry players. The paper and printing firms pioneering innovations have increased especially in optics, semiconductors, computer technology and in the basic communication processes related technologies, but compared to the other players paper \& printing companies had make substantially less pioneering innovations than the other industry players. In the sample there were totally 306 inventions which have received at least 100 citations, and from these innovations over $60 \%$ were made by integrated players. When looking ten most cited pioneering innovations (Table 6) we can see how dominant IBM have been in these breakthrough innovations. 


\begin{tabular}{|c|c|c|c|c|}
\hline $\begin{array}{l}\text { Industry / } \\
\text { IPC group }\end{array}$ & $\begin{array}{c}\text { Paper \& } \\
\text { Printing } \\
(\mathrm{N}=18)\end{array}$ & $\begin{array}{c}\text { Upstream } \\
\text { electronics } \\
(\mathrm{N}=\mathbf{2 6})\end{array}$ & $\begin{array}{c}\text { Vertically } \\
\text { integrated } \\
\text { electronics } \\
(\mathrm{N}=23) \\
\end{array}$ & $\begin{array}{c}\text { Downstream } \\
\text { electronics } \\
(\mathbf{N}=17)\end{array}$ \\
\hline All patents & 77,963 & 124,184 & 218,560 & 43,518 \\
\hline $\begin{array}{c}\text { Pioneering } \\
\text { innovations } \\
\text { (self-citations) }\end{array}$ & $\begin{array}{l}16,091 \\
(18.9 \%)\end{array}$ & $\begin{array}{c}26,855 \\
(31.7 \%))\end{array}$ & $\begin{array}{c}72,461 \\
(46.1 \%))\end{array}$ & $\begin{array}{c}8,459 \\
(50.9 \%)\end{array}$ \\
\hline $\begin{array}{c}\text { Citations received / } \\
\text { patent }\end{array}$ & $\begin{array}{c}2.72 \\
(43,747)\end{array}$ & $\begin{array}{c}5.36 \\
(143,829)\end{array}$ & $\begin{array}{c}3.42 \\
(247,834)\end{array}$ & $\begin{array}{c}9.40 \\
(79,546)\end{array}$ \\
\hline $\begin{array}{c}\text { TOP50 IPC } \\
(\% / \text { all })\end{array}$ & $83.0 \%$ & $83.7 \%$ & $90.1 \%$ & $98.1 \%$ \\
\hline $\begin{array}{l}\text { I Electrical } \\
\text { engineering }\end{array}$ & $26.1 \%$ & $75.0 \%$ & $88.8 \%$ & $95.9 \%$ \\
\hline II Instruments & $19.8 \%$ & $21.7 \%$ & $8.1 \%$ & $3.6 \%$ \\
\hline III Chemistry & $17.3 \%$ & $0.6 \%$ & $1.0 \%$ & $0.0 \%$ \\
\hline $\begin{array}{l}\text { IV Mechanical } \\
\text { engineering }\end{array}$ & $36.8 \%$ & $2.7 \%$ & $2.1 \%$ & $0.5 \%$ \\
\hline
\end{tabular}

Table 5. The players' pioneering innovations distribution

\begin{tabular}{|c|c|c|l|c|}
\hline Position & Applicant & Year & \multicolumn{1}{|c|}{ Technology field } & $\begin{array}{c}\text { Count of } \\
\text { cites }\end{array}$ \\
\hline 1 & I IBM & 1988 & Semiconductors & 434 \\
\hline 2 & IBM & 1996 & $\begin{array}{l}\text { Computer tech; } \\
\text { semiconductors }\end{array}$ & 412 \\
\hline 3 & IBM & 1985 & $\begin{array}{l}\text { Semiconductors; audio- } \\
\text { visual technology }\end{array}$ & 390 \\
\hline 4 & $\begin{array}{c}\text { Texas } \\
\text { Instruments }\end{array}$ & 1992 & Telecommunications & 376 \\
\hline 5 & IBM & 1993 & $\begin{array}{l}\text { Machine tools; } \\
\text { measurement; } \\
\text { semiconductors }\end{array}$ & 344 \\
\hline 6 & IBM & 1990 & $\begin{array}{l}\text { Measurement, audio-visual } \\
\text { technology }\end{array}$ & 328 \\
\hline 7 & IBM & 1990 & $\begin{array}{l}\text { Computer technology; } \\
\text { Digital communication }\end{array}$ & 320 \\
\hline 8 & IBM & 1994 & $\begin{array}{l}\text { Computer technology; } \\
\text { control; semiconductors; } \\
\text { telecommunications }\end{array}$ & 315 \\
\hline 10 & IBM & 1996 & Computer technology & 304 \\
\hline
\end{tabular}

Table 6 . The ten most cited pioneering innovations 
From the upstream players Texas Instruments and Symbol Technologies have made most of their pioneering innovations. Microsoft has clearly dominated the downstream players pioneering innovations, and Moore, Toppan printing, Weyerhaeuser, Dai Nippon and Avery Dennison have been strong paper \& printing companies in pioneering innovations. Interestingly, when looking also cites of second generations citations (Table 7), there seem to be huge variation between the first and second generation citations.

\begin{tabular}{|c|c|c|c|c|}
\hline Applicant & Year & Technology field & $\begin{array}{l}\text { Count of } \\
\text { cites }\end{array}$ & $\begin{array}{l}\text { Cites 2nd } \\
\text { generation }\end{array}$ \\
\hline Integrated/IBM & 1988 & Semiconductors & 434 & 2671 \\
\hline Integrated/IBM & 1996 & $\begin{array}{l}\text { Computer tech.; } \\
\text { semiconductors }\end{array}$ & 412 & 2442 \\
\hline Integrated/IBM & 1985 & $\begin{array}{l}\text { Semiconductors; audio- } \\
\text { visual technology }\end{array}$ & 390 & 5672 \\
\hline $\begin{array}{l}\text { Upstream/Texas } \\
\text { Instruments }\end{array}$ & 1992 & Telecommunications & 376 & 5268 \\
\hline $\begin{array}{l}\text { Upstream/Texas } \\
\text { Instruments }\end{array}$ & 1994 & $\begin{array}{l}\text { Computer tech.; control; } \\
\text { digital communication }\end{array}$ & 243 & 1230 \\
\hline $\begin{array}{l}\text { Upstream/Texas } \\
\text { Instruments }\end{array}$ & 1984 & $\begin{array}{l}\text { Micro-structural and } \\
\text { nano-technology; optics }\end{array}$ & 239 & 2732 \\
\hline $\begin{array}{l}\text { Downstream/ } \\
\text { Microsoft }\end{array}$ & 1996 & $\begin{array}{l}\text { IT methods for } \\
\text { management; digital } \\
\text { communication }\end{array}$ & 276 & 2625 \\
\hline $\begin{array}{l}\text { Downstream/ } \\
\text { Tibco Inc. }\end{array}$ & 1990 & $\begin{array}{l}\text { Computer tech.; digital } \\
\text { communication }\end{array}$ & 270 & 2931 \\
\hline $\begin{array}{l}\text { Downstream/ } \\
\text { Microsoft }\end{array}$ & 1996 & $\begin{array}{l}\text { IT methods for } \\
\text { management }\end{array}$ & 245 & 2081 \\
\hline $\begin{array}{l}\text { Paper \& printing } \\
\text { Moore }\end{array}$ & 1991 & $\begin{array}{l}\text { Computer technology; } \\
\text { audio-visual technology, } \\
\text { digital communication }\end{array}$ & 127 & 2961 \\
\hline $\begin{array}{l}\text { Paper \& printing } \\
\text { Moore }\end{array}$ & 1996 & $\begin{array}{l}\text { IT methods for } \\
\text { management }\end{array}$ & 114 & 600 \\
\hline $\begin{array}{l}\text { Paper \& printing } \\
\text { Toppan printing }\end{array}$ & 1993 & $\begin{array}{l}\text { Semiconductors; } \\
\text { electrical machinery, } \\
\text { apparatus, energy }\end{array}$ & 113 & 703 \\
\hline
\end{tabular}

Table 7. TOP3 cited pioneering innovations of the each player

The patents which have been cited both in first and second generation can be thought to be a real breakthrough and long lasting innovations, while some of the pioneering patents seem to be superseded quite quickly with some new innovations.

\section{Disscussion and conclusions}

The global intellectual protection system is a rich source of valuable technologies as well as signals of technical emergence. Citations of the common patents may indicate the 
convergence of technological competencies between firms in different industries toward solving a common problem or exploiting a common technology. The following of particular industrial sector patents may be detected as citations that allow both backward and forward searching from the patents. Such searching not only reveals inventors and assignees that may be valuable partners in technology assessment, but also cross-disciplinary citation and the linkage of fields through co-citation of a patent or technological field. Cross-fertilisation of ideas from other technical fields is frequently a rich source of new innovations in both basic science and the commercial sector (See Winter, 2000). In the paper \& printing and electronics industries, important technological innovations are moving them closer together as more cross-scientific research can enable the printing sector to utilise technological developments in the neighbouring disciplines. Patents and forward citations were used in trying to evaluate the significance of this industry transformation. The downside of using forward citations in evaluating the technological significance and the economic value is that they are not available until a substantial period after the granting of a patent, because time is needed to accumulate significant information about its citations. In practice this means that the analysis will be challenging for the evaluation of current or very recent innovations. In comparison, backward citations provide comparable information upon publication of the patent document and, consequently, they provide comprehensive results earlier. Differentiating between external and self-citations within and beyond industry citations aids to provide more comprehensive prospects of future industry evolution. In addition, selfcitations typically indicate a strong competitive position in the particular technology and the firms are in a position to internalise the knowledge created by their own development. The patents which have not been made any citations of previous patents (no prior art), but have been cited a lot (forwards) are called as pioneering innovations. These four different kinds of citations are used as a tool to find out the connection between technology development and trajectory changes in convergent environments.

The patent data were collected from 87 main players operating in the RFID value chain. In the empirical analysis, over 465,000 patents and their over 1.3 million forward citations were analysed in the years 1978-2006. The results of the study indicate that paper and printing companies still patent predominantly in mechanical technologies and chemicals, but increasingly in electronics technologies, suggesting that the industries are becoming more technologically convergent. The growing overlap of the technological fields in which different industrial sectors are operating show clear indications for convergence and strategically important knowledge of the future competitive area between are presented. This type of patent analysis helps companies to recognise trends early in the industry and take strategic decisions accordingly.

It seems evident that the importance of external innovation will increase and the winners will be those who succeed to capture external innovations from outside the company and learn to use collaborative R\&D. So it seems that the essential knowledge from beyond one's own industry is necessary and key to innovation management. Considering the whole electronics industry, the paper \& printing companies are still quite marginal players, although potentially quite huge new markets should be available when the technology progresses to low cost flexible substrates. Moreover, the self-citation analysis indicates that the paper and printing firms have received self-citations mainly in their traditional fields of core competencies and there have been not so much pioneering innovations compared to the players. Self-citations would then suggest that the firms have not yet a strong enough 
competitive position in the new fields. All in all, we see that patent citation analysis and convergence should be included in the research agenda of technology management and firm strategy.

\section{Acknowledgements}

The paper is an extended version of the 6th International Working Seminar on Production Economics, Innsbruck, March 1-5, 2010. The Authors would like to thanks conference participants for their valuable feedback and comments. In addition we want to thank Juha Kortelainen for his support in data analysis of this paper.

\section{References}

Aho, O. (2003), Combining conducting polymers with paper surface or fibres, Helsinki University of Technology, Laboratory of Paper Technology, Report, Functionalized paper (PAPU) project.

Bröring, S., Cloutier, M. L. \& Leker, J. (2006). The front end of innovation process in an era of industry convergence: evidence from nutraceuticals and functional foods, $R \mathcal{E D}$ Management, Vol. 36, Issue 5, pp. 487-498, 2006.

Curran, C., Bröring, S. \& Leker, J. (2010). Anticipating converging industries using publicly available data, Technological Forecasting \& Social Change, Vol. 77, Iss. 3, pp. 385395.

Curran, C., Leker, J. (2009). Seeing the Next iPhone Coming Your Way: How to Anticipate Converging Industries, PICMET 2009 Proceedings, August 2-6, Portland, Oregon USA.

Das, R., Harrop, P. (2008). RFID forecasts, players \& opportunities 2008-2018, IDTechEx Ltd. Cambridge.

Dowling, M., Lechner, C., Thielmann, B. (1998). Convergence: innovation and change of market structures between television and online services, Electronics Markets Journal, Vol 8. No. 4. pp. 31-35.

Duysteers, G., Hagedoorn, J. (1998). Technological Convergence in the IT Industry: The Role of strategic technology alliances and technological competencies, International Journal Economics of Business, 5(3), 355-368.

EPO Worldwide Patent Statistical Database, April 2008.

Fai, F., Tunzelmann von N. (2001). Industry-spesific competencies and converging technological systems: evidence from patents, Structural change and Economic Dynamics, Vol. 12, pp. 141-170, 2001

Fortunato, E., Correia, N., Barquinha, P., Pereira, L., Goncalves, G. \& Martins, R. (2008). High- Performance Flexible Hybrid Field-Effect Transistors Based on Cellulose Fiber Paper. IEEE Electron Device Letters. Vol. 29 Issue 2, pp. 988-990.

Griliches, Z. (1990). Patent Statistics as Economic Indicators: A Survey. Journal of Economic Literature, Vol. 28, pp. 1661-1707.

Hacklin, F. (2008). Management of Convergence in Innovation - Strategies and Capabilities for Value Creation Beyond Blurring Industry Boundaries. Physica-Verlag, Heidelberg, 2008. 
Hakola, L., Lindqvist, U., Linna, H., Siivonen, T. \& Södergård, C. (2006). Roadmap on printed functionality and hybrid media. 33rd International Research Conference of IARIGAI. Sept. 10-13, Leipzig, Germany.

Hall, B. H., Jaffe, A. B., Trajtenberg, M. (2005). Market value and patent citations, RAND Journal of Economics, Vol. 36 (1), 16-38.

Hall, B. H., Jaffe, A. B., Trajtenberg, M. (2001). The NBER Patent Citations Data File: Lessons, Insights, and Methodological tools, NBER Working Paper No. 8498, Cambridge, MA.

Harrop, P. \& Das, R. (2008). Introduction to Printed Electronics. IDTechEx Ltd. Cambridge, United Kingdom.

Jaffe, A. B., Trajtenberg, M., Fogarty, M. S. (2000). The Meaning of Patent Citations: Report on the NBER/CASE- Western Reserve Survey on Patentees. NBER Working Paper No. 7631, Cambridge, MA.

Kesola, I. (2007). Roll to Roll, cost effective integration of high-tech technology and traditional production methods. Pulpaper 2007 Conference, June, Helsinki. Finland.

Lai, K., Lin, M., Chang, S. (2006). Research Trends on Patent Analysis: An Analysis of the Research Published in Library's Electronic Databases, The Journal of American Academy of Business, Cambridge, Vol. 8, No. 2., pp. 248-253.

Lei, D. T. (2000). Industry evolution and competence development: the imperatives of technological convergence, International Journal of Technology Management, Vol. 19, pp. 699-738.

Lind, J. (2004). Convergence: History of term usage and lessons for firm strategists, In: ITS 15th Biennial Conference, Berlin, Germany. International Telecommunications Society (ITS), 2004.

Lynn, C. (2005). RFID and Printed Electronics: A new Opportunity for Printers?. Analyzing Publishing Technologies. Seybold Report: Analyzing Publishing Technologies. Vol. 4 Issue 24, pp 14-17.

Michel, J. \& Bettels, B. (2001). Patent citation analysis: A closer look at the basic input data from patent search reports, Scientometrics, Vol. 51, No 1, pp. 185-201.

Ngai, E., W., T., Moon, K., K., L., Riggins, F., J. \& Yi, C., Y. (2008). RFID research: An academic literature review (1995-2005) and future research directions. Journal of Production Economics. Vol 112 Issue 2, pp 510-520.

Pavel, P., Pavitt, K. (1997). The technological competencies of the world's largest firms: complex and path-dependent, but not much variety. Research Policy, Vol. 26, pp. 141-156.

Seppä, H. \& Uusikylä, M. (2009). Vallankumouksellinen RFID. Etätunnistusteknologian kehitys meillä ja maailmalla. Tekesin katsaus 249/2009. Tekes. Helsinki. Finland.

Smoch, U., Laville, F., Patel, P., Frietsch, R. (2003). Linking Technology Areas to Industrial Sectors, Final Report to European Commission, DG Research.

Stieglitz, N. (2003). Digital Dynamics and Types of Industry Convergence: The Evolution of the Handheld Computer Market, In Christensen, Jens F. (eds.) The Industrial Dynamics of the New Digital Economy. pp. 179-208.

Suoranta (2008). Open Modular Platform Architecture - A Key Enabler for Open Innovation. XIX ISPIM (International Society for Professional Innovation Management) Conference, Tours, France. 
Thoma, G., Torrisi, S. (2007). Creating Powerful Indicators for Innovation Studies with Approximate Matching Algorithms. A test based on PATSTAT and Amadeus databases. CESPRI Working Papers 211.

Trajtenberg, M. (1990). A Penny for Your Quotes: Patent Citations and the Value of Innovations. The Rand Journal of Economics, Vol. 21 (1), 172-187.

Winter, S. (2000). Appropriating the Gains from Innovation. In. Day, G. S., Schoemaker, P. J. H., \& Gunther, R. E. (eds.), Wharton on Managing Emerging Technologies. John Wiley \& Sons, New York, NY.

Wirtz, B.W. (2001). Reconfiguration of Value Chains in Converging Media and Communications Markets, Long Range Planning, Vol. 34, Vol 4, pp. 489-506.

World Intellectual Property Organization (2008). World patent report: A statistical review.

Wu, N.C., Nystrom., Lin, T. R., Yu H. C. (2006). Challenges to global RFID adoption. Technovation, Vol. 26, no. 12, pp. 1317-1323.

Österbacka, R. (2008). Intelligence in Printing. Signs of Renewal in the Forest Industry. Summer School 2008, Lappeenranta University of Technology, 9-10 September. Lappeenranta 


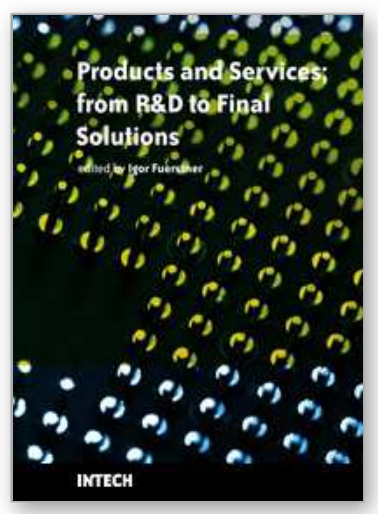

\author{
Products and Services; from R\&D to Final Solutions \\ Edited by Igor Fuerstner
}

ISBN 978-953-307-211-1

Hard cover, 422 pages

Publisher Sciyo

Published online 02, November, 2010

Published in print edition November, 2010

Todayâ€ $\mathrm{TM}^{\mathrm{TM}}$ global economy offers more opportunities, but is also more complex and competitive than ever before. This fact leads to a wide range of research activity in different fields of interest, especially in the socalled high-tech sectors. This book is a result of widespread research and development activity from many researchers worldwide, covering the aspects of development activities in general, as well as various aspects of the practical application of knowledge.

\title{
How to reference
}

In order to correctly reference this scholarly work, feel free to copy and paste the following:

Matti Karvonen and Tuomo Kässi (2010). Signals for Emerging Technologies in Paper and Packaging Industry, Products and Services; from R\&D to Final Solutions, Igor Fuerstner (Ed.), ISBN: 978-953-307-211-1, InTech, Available from: http://www.intechopen.com/books/products-and-services--from-r-d-to-final-solutions/signalsfor-emerging-technologies-in-paper-and-packaging-industry

\section{INTECH}

open science | open minds

\section{InTech Europe}

University Campus STeP Ri

Slavka Krautzeka 83/A

51000 Rijeka, Croatia

Phone: +385 (51) 770447

Fax: +385 (51) 686166

www.intechopen.com

\section{InTech China}

Unit 405, Office Block, Hotel Equatorial Shanghai

No.65, Yan An Road (West), Shanghai, 200040, China

中国上海市延安西路65号上海国际贵都大饭店办公楼 405 单元

Phone: +86-21-62489820

Fax: +86-21-62489821 
(C) 2010 The Author(s). Licensee IntechOpen. This chapter is distributed under the terms of the Creative Commons Attribution-NonCommercialShareAlike-3.0 License, which permits use, distribution and reproduction for non-commercial purposes, provided the original is properly cited and derivative works building on this content are distributed under the same license. 